DOI: $10.17516 / 1997-1370-0845$

УДК $347.45 / 47$

\title{
Legal Issues of Smart Contracts in Contract Law
}

\author{
Elizaveta V. Zainutdinova* \\ Novosibirsk State University \\ Novosibirsk, Russian Federation
}

Received 27.08.2020, received in revised form 20.07.2021, accepted 14.09.2021

\begin{abstract}
The research is carried out on some legal issues of smart contracts and their place in Russian and other countries' contract law. By means of contract law such issues are analysed: 1) conclusion and performance of smart contracts' obligations; 2) practical issues arising due to smart contracts' use; 3) contract law provisions that might be applied to smart contracts; 4 ) issues that are not covered by the legislation but need to be addressed. A smart contract is considered to be a contract with the specific type of performance of obligations (automated performance). Smart contract is a contract concluded with an exchange of data (type of a written form). Smart contracts are performed with the help of automated performance and previously expressed consent of parties. It is proved that smart contracts could be modified and terminated giving a mechanism for that as well as provides for measures of defence and responsibility that could be applied for obligations out of smart contracts. As the result, provisions of smart contracts that reflect smart contracts' place and peculiarities in contract law are formulated.
\end{abstract}

Keywords: Smart contract, contract law, performance of obligations, automated performance of obligations, mutual restitution.

Research area: law.

Citation: Zainutdinova, E.V. (2021). Legal issues of smart contracts in contract law. J. Sib. Fed. Univ. Humanit. soc. sci., 14(11), 1626-1634. DOI: 10.17516/1997-1370-0845

(C) Siberian Federal University. All rights reserved

* Corresponding author E-mail address: zainutdinovaev@gmail.com 


\title{
Правовые аспекты смарт-контрактов в договорном праве
}

\author{
Е.В.Зайнутдинова \\ Новосибирский государственньй университет \\ Российская Федерачия, Новосибирск
}

\begin{abstract}
Аннотация. Проводимое исследование посвящено правовым аспектам смартконтрактов и их месту в российском договорном праве, а также договорном праве других стран. С помощью инструментария договорного права анализируются такие аспекты: 1) заключение и исполнение обязательств из смарт-контракта; 2) практические вопросы, возникающие в связи с использованием смартконтрактов; 3) положения договорного права, которые могут быть применены к смарт-контрактам; 4) аспекты, которые не покрываются законодательством, но должны быть освещены и решены. Смарт-контракт рассматривается как договор с особым способом исполнения обязательств (автоматизированным исполнением). Смарт-контракт является договором, заключаемым путем обмена данными (разновидность письменной формы договора). Смарт-контракты исполняются при помощи автоматизированного исполнения и заранее выраженного согласия сторон. Доказано, что смарт-контракты могут быть изменены и прекращены с использованием указанных средств, а также возможно применять меры защиты и ответственности в отношении обязательств из смарт-контракта. В результате автором формируются положения о смарт-контрактах, которые отражают место и особенности смарт-контрактов в договорном праве.
\end{abstract}

Ключевые слова: смарт-контракт, договорное право, исполнение обязательств, автоматизированное исполнение обязательств, двусторонняя реституция.

Научная специальность: 12.00 .00 - юриспруденция.

\section{Introduction}

The smart contract term though not legal in its nature has a long story in the legal field. It was mentioned in Russia in legal bill «On digital financial assets» ${ }^{1}$ and Federal Law of 18 March, 2019 No. 34-FZ «On Amendments to the First, Second Parts and Article 1124 of the Third Part of the Civil Code of the Russian Federation $\rangle^{2}$ aimed at regulating execution of

\footnotetext{
1 In the First Hearing the Bill on Digital Financial Assets was Enacted. State Duma of the Russian Federation [V Pervom Chtenii Priniat Zakonoproekt o Cifrovykh Finansovykh Aktivakh. Gosudarstvennaia Duma Rossiiskoi Federatsii], available at: http://duma.gov.ru/news/27027/ (accessed 30 July 2020).

2 Federalniy Zakon ot 18.03.2019 № 34-FZ «O Vnesenii Izmenenij v Chasti Pervuyu, Vtoruyu i Statiyu 1124 Chasti Tretiej Grazhdanskogo Kodeksa Rossijskoj Federacii» [Federal Law of 18 March, 2019 No. 34-FZ «On Amendments to the First, Second Parts and Article 1124 of the Third Part of the Civil Code of the Russian Federation»], available at: http://publi-
}

rights and performance of obligations arising from smart contracts. However, definition of a smart contract and smart contracts' provisions are not developed in the legal doctrine yet, and a lot of legal issues regarding practical application of smart contracts remain unresolved.

\section{Theoretical framework}

Legal issues arising out of smart contracts' use have been thoroughly analysed in legal literature both abroad and in Russia. However, these issues are still considered to be quite new and not fully discovered. Doing research, the author analysed such seminal publications by foreign authors as «Digital Technology as a Challenge to European Contract Law» (S. Grundmann, P. Hacker), «For-

cation.pravo.gov.ru/Document/View/0001201903180027?in$\mathrm{dex}=2$ \&rangeSize $=1$ (accessed 30 July 2020). 
malizing Contract Law for Smart Contracts» (E. Tjong Tjin Tai), «Smart Contracts and the Cost of Inflexibility» (J.M. Sklaroff), «Smart Contracts - How Will Blockchain Technology Affect Contractual Practices?» (K. Lauslahti, J. Mattila, T. Seppala), «The Deformation of Contract in the Information Society» (M. J. Radin).

In Russia there have been publications regarding different aspects of smart contracts, however, there are still a lot of debate concerning smart contract's nature. Among those are such publications as «Nekotorye Pravovye Aspekty Ispol'zovaniia Smart-Kontraktov i Blokchejn-Tekhnologij po Rossijskomu Pravu» [«Some Legal Issues Concerning Smart Contracts' and Blockchain Technology' Use in Russian Law»] (A. I. Savel'ev), «O Nekotorykh Perspektivakh Razvitiia Umnogo Kontrakta kak Osobogo Instrumenta v Oblasti Zakliucheniia i Ispolneniia Grazhdansko-Pravovykh Dogovorov» [«On Some Perspectives of Smart Contract's Development as a Special Tool in the Field of Conclusion and Performance of Civil Law Contracts»] (A.I. Guliaev, S. V. Novikova), «Smart-Kontrakty v Rossii: Perspektivy Zakonodatel'nogo Regulirovaniia» [«Smart Contracts in Russia: Perspectives of Legal Regulation»], (D. S. Diad'kin, Y.M. Usol'tsev, N.A. Usol'tseva), «Tokeny, Kriptovaliuty i Smart-Kontrakty v Otechestvennyh Zakonoproektakh s Pozitsii Inostrannogo Opyta» [«Tokens, Cryptocurrency and Smart Contracts in National Draft Bills from the Foreign Perspective»] (D. V. Fedorov) as well as publications on e-contracting in a whole (in particular, «Russian Business Law» (V.N. Lisitsa (ed.)., E. V. Somova)) or on improving effectiveness of law for better business activity (Nekotorye Aspekty Povysheniia Effektivnosti Ugolovnogo Zakona v Sfere Ekonomiki: Razrabotka Kategorial'nogo Apparata [Some Aspects of Impoving Effectiveness of the Criminal Law in the Field of Economy: Developing the Categories] (V.N. Lisitsa, S. V. Parkhomenko).

Therefore, carrying out research, the author analyses both foreign and national publications, and makes a conclusion that we need to take into account foreign initiatives and foreign authors' views while still developing our own doctrine on smart contracts. The general points are an approach to contracts as to agreements of parties and classification of contracts from Roman law that was appropriated in Russian civil law.

\section{Statement of the problem}

The revolutionary idea of smart contracts is that parties can transfer digital assets on their own terms previously specified without any intermediaries and reliance on any centralized entity. This is to be described by legal means in legislative acts and legal doctrine. Until the present time there has been no clear explanation how smart contracts are performed and what type of contracts they belong to. Therefore, the objectives that the author has are the following: to define smart contracts namely by the means of contract law making a legally crafted definition, and consider smart contracts' legal issues, i. e. their conclusion, performance, modification and termination, application of measures of defence and responsibility in regards of smart contracts.

\section{Methods}

Methods the author uses consist of methods of legal formal analysis, legal comparative analysis and historical analysis. The method of legal formal analysis helps to research the legal nature of smart contracts and legal issues that arise due to smart contracts' practical application. The legal comparative method and the method of historical analysis help to look into the character of smart contracts' legal regulation in different jurisdictions, and possibilities of smart contracts development in Russian law.

\section{Discussion}

\subsection{Smart contract's definition and its characteristics in literature}

We could define a smart contract as an agreement of parties written by programming code in blockchain information system (Savel'ev, 2016, 2017). Conditions of smart contracts are enforced through a platform called distributed ledger (one of which is known as blockchain). Data about transactions are stored on blockchain where chains of blocks represent sequences of transactions (Antonopoulos, 
2010). In other words, changing information in one block is impossible without changing information in all other blocks which cannot be done by one participant of blockchain information system (Miles, 2017). This makes the exchange of goods and services more secure and reliable for parties.

What are other characteristics and advantages of smart contracts differentiating them from other contracts? Entering into smart contracts requires less expenditure because parties do not need to negotiate, search and process information. They express their expectations in blockchain information system and a contract is concluded when expectations of parties are met. Using blockchain technology for «smart contracts» greatly reduces transaction costs because smart contracts programmed into the blockchain are performed automatically and immediately.

Smart contracts do not require third parties to clear and secure transactions. The process of payment and receipt of a good or service is simultaneous and is controlled by participants of blockchain information system. When parties' conditions are met, a smart contract is concluded. In case of non-payment a good may be recovered or a service may be suspended. There is no risk in smart contracts comparing with other contracts in transfer rights on property (Iagubova, 2018). For example, until seller pays for property in full he does not acquire the right on this property. Firstly, buyer's money gets frozen and information about the seller title is checked, after which smart contract is performed automatically.

Consequently, it seems that smart contracts are quite likely to dominate in the future because they reduce transaction costs imposed by principals or third parties, facilitate contracting process by user-friendly interfaces (Szabo, 1997). The digital relationships appear to be more functional than paper-based contracts (Szabo, 1996). We can conclude that smart contracts are cheaper, quicker, and more efficient (O'Shields R.). These contracts provide parity or a possibility for both parties to choose and agree on preferable contract conditions (Lisitskaia). Smart contracts are formed between parties only if conditions of both parties are met, for example, when one party desires to sell securities for a particular price and the other party accepts its conditions, including price, before entering into agreement. Moreover, it is believed that the use of smart contracts will shift the balance of power and bargain between consumers and producers. Smart contracts based on blockchain technology can potentially restructure relationship between consumers and intermediaries online (Fairfield). Instead of just agreeing to proposed terms, consumers could actually contract again. Nowadays consumers are constrained by the form of the webpage from offering other terms, such as reservations of rights and warranties. What is needed is a format in which consumers can express their preferences and then expect their preferences to be enforced. That is what smart contracts have a potential to do.

\subsection{Author's definition of a smart contract}

Despite occurrence of some definitions of a smart contract in doctrine (Oleinik, p. 310) it was not analysed whether it is a contract in terms of contract law and what type of contract it is. The author analyses correlation of a «smart contract» with such terms as «contract» and «execution of obligations». On this basis, the conclusion is made that a smart contract is a type of electronic contracts (special type of a written form). However, origin of a smart contract is interconnected with the appearance of a new way of performing obligations by which obligations are fulfilled automatically. The author supposes that we may define a smart contract as a contract with the specific type of performance of obligations, namely with automated performance. Strictly speaking, smart contracts are not actually a new type of contracts, rather they are more likely to introduce a new type of performance of obligations than a new type of contracts.

\subsection{Smart contract's conclusion}

Smart contract provisions are written in the form of programming code. Smart contract specific nature is a result of use of blockchain information system (or other decentralised distributed information system) for conclusion of smart contracts. Herewith a contract is con- 
cluded when an acceptance of an offer is made in this information system for conclusion of smart contracts. This type of concluding contracts is described in the Russian Civil Code in the part devoted to concluding contracts with an exchange of data ${ }^{3}$. Conclusion and verification of smart contracts in the information system makes it possible for parties not to draft typical legal agreements in printed form and provides an opportunity to secure data.

\subsection{Smart contract's performance}

Characteristics of smart contracts' performance are seen in automated performance of obligations. Smart contracts are performed automatically but with the parties' consent. With the help of civil law doctrine we may introduce a category of parties' previously expressed consent that helps us to define who is to enter into a deal. The point is that a party that gave its previously expressed consent on performance of obligations with the use of electronic platform cannot influence the process of performance of obligations. It seems that for obligations from smart contracts that are performed automatically we need to apply existing in law rules on performance of obligations as well as distinct provisions that specify automated performance of obligations because performance of obligations from smart contracts has its own legal characteristics. The main difference and advantage of smart contracts is that performance of obligations from a smart contract makes undue performance impossible (Mineev, 2013); performance of obligations from a smart contract is always due, it is determined by the use of software and decentralised distributed information system.

Automated performance of obligations and previously expressed consent on performance of obligations are new categories in Russian contract law but it looks as if that these are quite appropriate for describing smart contracts in doctrine and legislative acts. The author proposes to use them in the following way: «An obliged party while concluding a smart

\footnotetext{
3 Grazhdanskii Kodeks Rossiiskoi Federatsii (Chast' Pervaia) ot 30.11.1994 № 51-FZ [Civil Code of the Russian Federation (Part One) of 30.11.1994 № 51-FZ], Art. 434, available at: http://www.consultant.ru (accessed 30 July 2020).
}

contract gives its consent for automated performance of obligations that cannot be changed or revoked by this party after receiving a consent for performance of obligations from the other party» (Mineev, 2013). And it seems that the other party gives its consent for performance of obligations when this party actually gives its consent for conclusion of a smart contract.

\subsection{Smart contract's modification and termination}

This issue about modification and termination arises, for example, when omissions or errors inside smart contracts are noted. Smart contracts written as software programs in blockchain information system per se cannot be modified. These contracts are executed by computer, their enforcement is not to be abolished as technically chain of blocks in blockchain information system cannot be changed. By the way, problems with smart contracts are inevitable because of bounded rationality of coders and contracting parties, incomplete foresight, incomplete information, and opportunistic behaviour (Calcaterra, Kaal, 2018). To solve this, we need a mechanism of returning transaction under conditions verified in a smart contract. Mechanism of returned transaction provides for mutual restitution. It is also possible that a court or an arbitrator may force a party or parties to modify or terminate a smart contract in case it violates the law.

\subsection{Application of measures of defence and responsibility as regards smart contracts}

Having analysed practice of application of smart contracts, we conclude that mutual restitution (restoration) as well as unilateral restitution may be applied to smart contracts. For example, restoration was applied in $\mathrm{B} 2 \mathrm{C} 2 \mathrm{Ltd}$ v. Quoine Pte Ltd. Case by platform operator. Smart contract in this case was contract of exchange of cryptocurrencies. Due to the technical glitch the market-maker B2C2 bought bitcoins for the price which was 250 times lower than the market price. The platform operator terminated these deals and returned to the parties their cryptocurrencies. However, the market-maker went to the court in Singapore. 
The court, however, ruled that the plaintiff is right since in the user agreement between the platform and the market maker was no provision giving the platform right to terminate the deals (smart contracts) as well as that the technical glitch could have been controlled by the platform operator but it had not dealt with it ${ }^{4}$. Therefore, we see that even if there is a contradiction of a smart contract to such legal principles as fair faith and reasonability it may be not possible to terminate it.

A smart contract could be nullified as the courts' practice shows. In case of hacking attack such measure as unilateral restitution was applied after the smart contract was nullified. The defendants who made the hacking attack forced the plaintiff to pay in bitcoins for the software that could beat this attack. The court nullified such smart contract and applied the freezing order in regard to the defendants' property ${ }^{5}$. In other case a smart contract was nullified due to the fact that the defendant concluded the smart contract by technical mistake ${ }^{6}$.

Such remedy as specific performance may be applied only if performance was not made due to malfunction of blockchain information system since in other cases smart contracts are duly performed. In such a case the malfunction could be result of third parties actions (like hacking attack) or even of parties actions (when such party hinders the performance of its obligations out of a smart contract by technical means).

It is a tricky issue whether we could apply unjust enrichment for obligations out of a smart contract or not. If parties voluntarily conclude a smart contract the court cannot apply unjust

\footnotetext{
4 Judgement of the Singapore International Commercial Court of the Republic of Singapore [2019] SGHC(I) 03. Suit No 7 of 2017 between B2C2 Ltd and Quoine Pte Ltd, available at: https://www.sicc.gov.sg/docs (accessed 30 July 2020).

5 AA v. Persons Unknown who Demanded Bitcoin on $10^{\text {th }}$ and $11^{\text {th }}$ October 2019, Persons Unknown who Own/Control Specified Bitcoin, iFinex Trading as Bitfinex, BFXWW INC Trading as Bitfinex Case No: CL-2019-000746 Approved Judgement 13 December 2019. The High Court of Justice. Business and Property Courts of England and Wales, available at: https://www.conyers.com (accessed 30 July 2020).

6 Chwee Kin Keong and Others v. Digilandmall.com Pte Ltd [2004] 2 SLR594; [2004] SGHC71. Suit 202/2003/E. 12 April 2004. High Court, available at: http://www.cisg-online.ch/ content/api/cisg/urteile/1641.pdf (accessed 30 July 2020).
}

enrichment for such obligations since there is contractual relationship between the parties? However, in cases when there is a hacking attack such measure may be applied (like the DAO's case when more than 40 million dollars were stolen (Dushaeva, 2018). But in this case the platform operator applied unilateral restoration returning money to platform users. In cases when smart contract was concluded due to a mistake courts may apply unjust enrichment $^{8}$.

Such special measures as request to transfer a private key as well as to abstain from using a private key, recovery of a record in information system are applied to smart contracts. These are new civil law measures which appeared due to the use of smart contracts. Request to transfer a private key makes it possible to get an access to digital financial assets in ewallet. Request to abstain from using a private key helps to keep digital financial assets in ewallet for the private key's right holder or his successors. Recovery of a record in information system is a particular case of application of restoration of the situation which existed prior to the violation of right.

As for application of measures of responsibility, we face the position that smart contracts are duly performed, therefore, any measures of responsibility cannot be applied to them (Savel'ev, 2016, 2017). However, this is not true since technical glitches and mistakes are inevitable as well as hacking attacks or even

\footnotetext{
Apelliatsionnoe Opredelenie Verkhovnogo Suda Respubliki Bashkortostan ot 20.02.2017 po delu № 33-3487/2017 [Appellate Ruling of the Supreme Court of the Republic of Bashkortostan of 20.02.2017, case № 33-3487/2017], available at: https://vs - bkr.sudrf.ru (accessed 30 July 2020); Apelliatsionnoe Opredelenie Ul'ianovskogo oblastnogo suda ot 31.07.2018 po delu № 33-3142/2018 [Appellate Ruling of the Ulyanovsk Regional Court of 31.07.2018, case № 333142/2018], available at: https://www.audar-info.ru (accessed 30 July 2020).

8 Luno Pte Ltd, Bitx Malaysia Sdn Bhd v. Robert Ong Thien Cheng. Civil Suit No: BA-B52NCVC-389-12/2017. 15 November 2018. The Sessions Court at Shah Alam in the State of Selangor Darul Ehsan, Malaysia, available at: http://foongchengleong.com (accessed 30 July 2020); Robert Ong Thien Cheng v. Luno Pte Ltd, Bitx Malaysia Sdn. Bhd. Appeal No: 12BNCVC-91-10/2018. 31 August 2019. The High Court of Malaya at Shah Alam in the State of Selangor Darul Ehsan, available at: http://foongchengleong.com (accessed 30 July 2020).
} 
intent of a party to hinder performance out of a smart contract. In these cases we may apply not only measures of defence but also measures of responsibility. For a party or a programmer who wrote a smart contract it would be responsibility in the form of recovery of damages in full or in particular sum of money as stated in a contract. For a party this contract is a smart contract, for a programmer this is a contract on providing services on writing a smart contract. For a hacker it would be responsibility in the form of recovery of damages which were incurred due to the attack.

\section{Conclusion}

As a conclusion, the author would like to point out that characteristics and contractual nature of smart contracts promise a big future for them, even given the risks of issues on terminating, modifying smart contracts, applying measures of defence and responsibility are still new and debatable and not fully resolved. We have a task to adequately accommodate this new type of contracts in legal systems taking into account their origin in distributed ledger technology and their role as parties' agreements to transfer property.

We may define a smart contract as a contract with the specific type of performance of obligations, namely with automated performance. Smart contracts introduce a new type of performance of obligations but not a new type of contracts. A smart contract is concluded when an acceptance of an offer is made in information system for conclusion of smart contracts. This type of concluding contracts is present in the Russian Civil Code type of concluding electronic contracts. The author proposes to use such categories as automated performance of obligations and pre- viously expressed consent on performance of obligations in the following way: "An obliged party gives its consent for performance of obligations with the use of smart contracts (automated performance of obligations) that cannot be changed or revoked by this party after receiving a consent for performance of obligations from the other party». And it seems that the other party gives its consent for performance of obligations when this party actually gives its consent for conclusion of a smart contract.

Smart contracts written as software programs on distributed ledgers per se cannot be modified. To solve this, we may use a mechanism of returning transaction under conditions verified in a smart contract. The mechanism of returned transaction could also be used as a remedy in situations when we face erroneous performance from a smart contract due to an omission in smart contractual provisions. Parties may also modify a smart contract including cases when it violates the law. Such measures of defence could be applied to smart contracts: mutual restitution (restoration), unilateral restitution (restoration), nullification, specific performance, unjust enrichment (not for the parties of a smart contract) as well as special measures of defence such as request to transfer a private key, request to abstain from using a private key, recovery of a record in information system. We could also apply measures of responsibility in regard to obligations out of a smart contract to a party of a smart contract, a programmer who wrote a smart contract or a third party (like a hacker) in the form of recovery of damages in full or in particular sum of money (liquidated damages - for a party of a smart contract or a programmer).

\section{References}

Antonopoulos, A.M. (2010). Mastering Bitcoin. O’Reilly Media, Inc., 263 p.

Calcaterra, C., Kaal, W.A. (2018). Crypto Transaction Dispute Resolution, In Business Lawyer, 17-12, available at: https://papers.ssrn.com/sol3/papers.cfm?abstract_id=2992962 (accessed 30 July 2020).

Diad'kin D.S., Usol'tsev, Y.M., Usol'tseva, N.A. (2018). Smart-Kontrakty v Rossii: Perspektivy Zakonodatel'nogo Regulirovaniia [Smart Contracts in Russia: Perspectives of Legal Regulation]. In Universum: Ekonomika i Iurisprudentsiia [Universum: Economics and Jurisprudence], 5, available at: https://cyberleninka.ru (accessed 30 July 2020). 
Dushaeva, A.A. (2018). The DAO - Detsentralizovannaia Avtonomnaia Organizatsiia [The DAO-Decentralized Autonomous Organization], available at: https://www.academia.edu (accessed 30 July 2020).

Fairfield, J. (2014). Smart Contracts, Bitcoin Bots, and Consumer Protection, In Washington and Lee Law Review Online, 71, available at: http://scholarlycommons.law.wlu.edu/cgi/viewcontent. cgi?article $=1003 \&$ context $=$ wlulr-online (accessed 30 July 2020).

Fedorov, D.V. (2018). Tokeny, Kriptovaliuty i Smart-Kontrakty v Otechestvennykh Zakonoproektakh s Pozitsii Inostrannogo Opyta [Tokens, Cryptocurrency and Smart Contracts in National Draft Bills from the Foreign Perspective], In Vestnik Grazhdanskogo Prava [Civil Law Review], 2, 30-74.

Grundmann, S., Hacker, P. (2017). Digital Technology as a Challenge to European Contract Law, In European Review of Contract Law, Vol. 13, Issue 3, 255-293.

Gulyaev, A.I., Novikova, S.V. (2018). O Nekotorykh Perspektivakh Razvitiia Umnogo Kontrakta kak Osobogo Instrumenta v Oblasti Zakliucheniia i Ispolneniia Grazhdansko-Pravovykh Dogovorov [On Some Perspectives of Smart Contract's Development as a Special Tool in the Field of Conclusion and Performance of Civil Law Contracts], In Epomen, 13, 18-29.

Iagubova, Iu.R. (2018). Problemy Primeneniia Norm Dogovornogo Prava k Smart-Kontraktam, Osushchestvliaemym v Informatsionnoi Platforme Blokchein [Problems of Application of Contract Law Provisions to Smart Contracts Performed at Blockchain Platform], In Vestnik sovremennyh issledovanii [Bulletin of Modern Research], 4,1, 394-396.

Komashko, M.N. (2010). Restitutsiia kak Sposob Zashchity Prava: Avtoref. ... Diss. Kand. Yurid. Nauk [Restitution as a Remedy: Abstract of Thesis of Doctor of Juridical Sciences]. Moscow, $31 \mathrm{p}$.

Lauslahti, K., Mattila, J., Seppala, T. (2017). Smart Contracts - How Will Blockchain Technology Affect Contractual Practices? In the Research Institute of the Finnish Economy (ETLA) Reports, 68, available at: https://www.etla.fi/wp-content/uploads/ETLA-Raportit-Reports-68.pdf (accessed 30 July 2020).

Lisitsa, V.N. (ed.)., Gromozdina, M.V., Voronkova, E.R., Voytovich, E.P., Lisitsa, I.V., Pachkova, P.S., Somova, E.V. (2019). Russian Business Law. Novosibirsk State University, Institute of Philosophy and Law, 392 p.

Lisitsa, V.N., Parkhomenko, S.V. (2018). Nekotorye Aspekty Povysheniia Effektivnosti Ugolovnogo Zakona v Sfere Ekonomiki: Razrabotka Kategorial'nogo Apparata [Some Aspects of Impoving Effectiveness of the Criminal Law in the Field of Economy: Developing the Categorial Classification], In Vserossiiskii Kriminologicheskii Zhurnal [Russian Journal of Criminology], 2, 190-198.

Lisitskaia, A. Iu. (2017). Nespravedlivye Dogovornye Usloviia v Grazhdanskom Prave Rossii i za Rubezhom: Sravnitel'no-Pravovoj Analiz [Unfair Contract Provisions in Civil Law in Russia and abroad: Comparative Legal Analysis], In Vestnik VEGU [Bulletin of Eastern Academy of Economics and Law Humanities], 6, 150-156.

Miles, C. (2017). Blockchain Security: What Keeps your Transaction Data Safe? In Blockchain Unleashed: IBM Blockchain Blog, available at: https://www.ibm.com/blogs/blockchain/2017/12/blockchainsecurity-what-keeps-your-transaction-data-safe/ (accessed 30 July 2020).

Mineev, O.A. (2013). Problemy Realizatsii Printsipa Nadlezhashchego Ispolneniia Obiazatel'stv v Sovremennom Grazhdanskom Oborote [Problems of Realization of the Principle of Due Performance of Obligations in Contemporary Civil Order], In Vestnik Volgogradskogo Gosudarstvennogo Universiteta Science [Journal of VolSU] 1, 35-39.

Oleinik, E.V. (2018). Smart-Kontrakt: Poniatie i Perspektivy Razvitiia v Rossii [Smart Contact: Term and Perspectives of Development in Russia], In Teoriia i Praktika Razvitiia Predprinimatel'stva: Sovremennye Kontseptsii, Tsifrovye Tekhnologii i Effektivnaia Sistema [Theory and Practice of Development of Entrepreneurship: Modern Concepts, Digital Technologies and an Effective System]. Materialy VI Mezhdunarodnogo Nauchnogo Kongressa pod Nauchnoi Redaktsiei A. V. Sharkovoi, O. N. Vasil'evoi, B. Otorovoi [Proceedings of the VI International Scientific Congress by A. V. Sharkovoi, O. N. Vasil'evoi, B. Otorovoi (eds.)], 309-313.

O'Shields, R. (2017). Smart Contracts: Legal Agreements for the Blockchain, In North Carolina Banking Institute, 21, available at: https://scholarship.law.unc.edu/cgi/viewcontent.cgi?referer=https://www.google.com/\&httpsredir=1\&article $=1435 \&$ context $=$ ncbi (accessed 30 July 2020). 
Radin, M.J. (2017). The Deformation of Contract in the Information Society, In University of Michigan Law School Law \& Economics Working Papers, 124, available at: https://repository.law.umich.edu (accessed 30 July 2020).

Savel'ev, A.I. (2016). Dogovornoe Pravo 2.0: «Umnye» Kontrakty kak Nachalo Kontsa Klassicheskogo Dogovornogo Prava [Contract Law 2.0: «Smart» Contracts as the Beginning of the End of Classic Contract Law], In Vestnik Grazhdanskogo Prava [Civil Law Review], 3, 32-60.

Savel'ev, A.I. (2017). Nekotorye Pravovye Aspekty Ispol'zovaniia Smart-Kontraktov i BlokcheinTekhnologii po Rossiiskomu Pravu [Some Legal Issues Concerning Smart Contracts' and Blockchain Technology Use in Russian Law], In Zakon [Law], 5, 94-117.

Sklaroff, J.M. (2017). Smart Contracts and the Cost of Inflexibility, In University of Pennsylvania Law Review, 166, 263-303.

Szabo, N. (1996). Smart Contracts: Building Blocks for Digital Markets, available at: http://www.fon. hum.uva.nl/rob/Courses/InformationInSpeech/CDROM/Literature/LOTwinterschool2006/szabo.best.vwh. net/smart_contracts_2.html (accessed 30 July 2020).

Szabo, N. (1997). Smart Contracts: Formalizing and Securing Relationships on Public Networks, In First Monday, 2 (9), available at: http://ojphi.org/ojs/index.php/fm/article/view/548/469 (accessed 30 July 2020).

Tjong Tjin Tai, E. (2017). Formalizing Contract Law for Smart Contracts, In Tilburg Private Law Working Paper Series, 6, available at: http://www.cs.bath.ac.uk/smartlaw2017/papers/SmartLaw2017_paper_1.pdf (accessed 30 July 2020). 